\title{
Variation of nitrogen forms in lakes with different intensity of anthropogenic pressure
}

\author{
Rafał Zieliński, Julita Dunalska, Jolanta Grochowska, Izabela Bigaj, Daniel Szymański \\ University of Warmia and Mazury, Department of Water Protection Engineering, Prawocheńskiego 1, 10-720 Olsztyn, Poland, \\ e-mail: rafal.zielinski@uwm.edu.pl (corresponding author), \\ julita.dunalska@uwm.edu.pl,jgroch@uwm.edu.pl,izabela.piorkowska@uwm.edu.pl,daniel.szymanski@uwm.edu.pl,
}

\begin{abstract}
The aim of this study was to compare the concentration of nitrogen and trace the dynamics of its changes in two lakes with different intensity of anthropogenic pressure. The dominant land use of Lake Paskierz catchment is built-up areas, while in Lake Sajmino, wasteland is the dominant land use. The total amount of nitrogen in Lake Paskierz ranged from 1.68 to $6.58 \mathrm{~g} \mathrm{~N}_{\text {tot }} \mathrm{m}^{-3}$, while in Lake Sajmino it was from 1.03 to $1.84 \mathrm{~g} \mathrm{~N}_{\text {tot }} \mathrm{m}^{-3}$. The organic fraction was a dominant form in the surface water layers of the examined lakes. A slightly different situation was found in near-bottom water layers of Lake Paskierz, where ammonium nitrogen was the dominant form in the summer stagnation. In other cases organic nitrogen was a dominant form in each of the reservoirs. Concentrations of nitrites and nitrates were low and did not affect essentially the overall amount of nitrogen in the studied lakes. Based on the results, it can be concluded that Lake Paskierz is overfertilized. The high concentrations of ammonia measured in near-bottom layers of the lake indicate that the internal supply may be a very important process affecting the trophic status. Lake Sajmino was characterized by significantly less nitrogen abundance, although the periodically increasing nitrogen concentration reveals the presence of adverse anthropopressure on the lake.
\end{abstract}

Key words: lake, nitrogen, anthropogenic eutrophication, catchment

\section{Introduction}

Lakes are specific freshwater ecosystems, considered as the most valuable components of the hydrosphere in nature, but also exceptionally short-lived and susceptible to damage. They perform many important hydrological, biocoenotic, microclimatic and economic functions. Lakes are primarily a shelter and a habitat of aquatic organisms, but also an essential store of water, a site of fisheries production and a refuge for many species of animals (BajkiewiczGrabowska 2002; Kostecki and Krodkiewska 2005; Jarosiewicz and Hetmański 2009).

The nutrient pollution level affects the rate of eutrophication. Excessive lake fertility limits possible use of lake water for industrial, municipal and recreational purposes. It may also cause certain economic effects, such as higher costs of water treatment, losses in fish stock, lower income from tourism and recreation. Additionally, eutrophication is considered to be the greatest threat to biodiversity in freshwater habitats (Kajak 2001; Upadhyay et al. 2011).

The rate of eutrophication depends on many morphometric, hydrographic and basin factors. Usually, this process is very slow in nature. However, intensified anthropopressure has caused a significant increase in eutrophication in recent decades. Changes in basin land use related with a high deforestation rate for the purposes of urbanization, undoubtedly contributed to the acceleration of eutrophication (Lossow 2000; Camargo and Alonso 2006). Just since 1954 the number of Polish lakes has decreased by 2215 and their surface reduced by about 11.22\% (Choiński 2007).

Nitrogen is one of the main elements that determine the increased pace of eutrophication. Its excess in lakes is currently a very frequent problem, especially in agricultural areas. In the surface waters nitrogen may occur as molecules $\left(\mathrm{N}_{2}\right)$ or in mineral (ammonium, nitrites and nitrates) and organic (dissolved and molecular) form. Mineral fractions of nitrogen have 
high solubility, thus they enter the basin primarily in this form. In turn, erosion of soil particles and leaching of dissolved organic matter are the main sources of organic nitrogen in water bodies (Kajak 2001).

Seasonal variation of mineral nitrogen forms depends on varying intensity of ammonification, nitrification and denitrification processes, which are regulated by oxygen concentration ( $\mathrm{Hu}$ et al. 2013). Organic nitrogen forms dominate usually during the growing season, while in winter ammonium nitrogen is more frequent (Kajak 1979). A large amount of ammonia nitrogen may occur from November to March (especially in polluted surface waters). During this period a low temperature prevails, which reduces its consumption by organisms and significantly decreases the intensity of the nitrification process. Ammonium ions are also present in the anoxic deep waters. Nitrite forms are unstable and in aerobic conditions they are rapidly oxidized to nitrates, whereas in anaerobic conditions they are reduced to ammonium forms. Therefore, the concentration of nitrites is usually low. In well-oxygenated water, nitrates are the dominant form of mineral nitrogen (Kajak 2001).
The aim of this study was to compare the concentration of nitrogen and to trace the dynamics of its changes in two lakes with different degrees of anthropopressure.

\section{Study area}

According to the physico-geographical division of Poland (Kondracki 2001) Lake Paskierz (Persian Lake) is located in the Masurian Lake District, in the mesoregion called the Olsztyńskie Lake District. This lake is situated northeast of Ostróda. The water table is approximately 97.0 metres above sea level (Fig. 1).

This small and relatively shallow lake has a poorly developed shoreline, a regular lake basin with a muddy bottom, high and in parts quite steep shores. Morphometric parameters of Lake Paskierz are shown in Table 1.

To the northeast, Lake Paskierz is connected with Lake Rudat and to the southwest with Pauzeńskie Lake (Anon. 2009). The catchment area of the analysed lake is small (29.4 ha) and mostly anthropogenically transformed. The dominant share of the land use is a

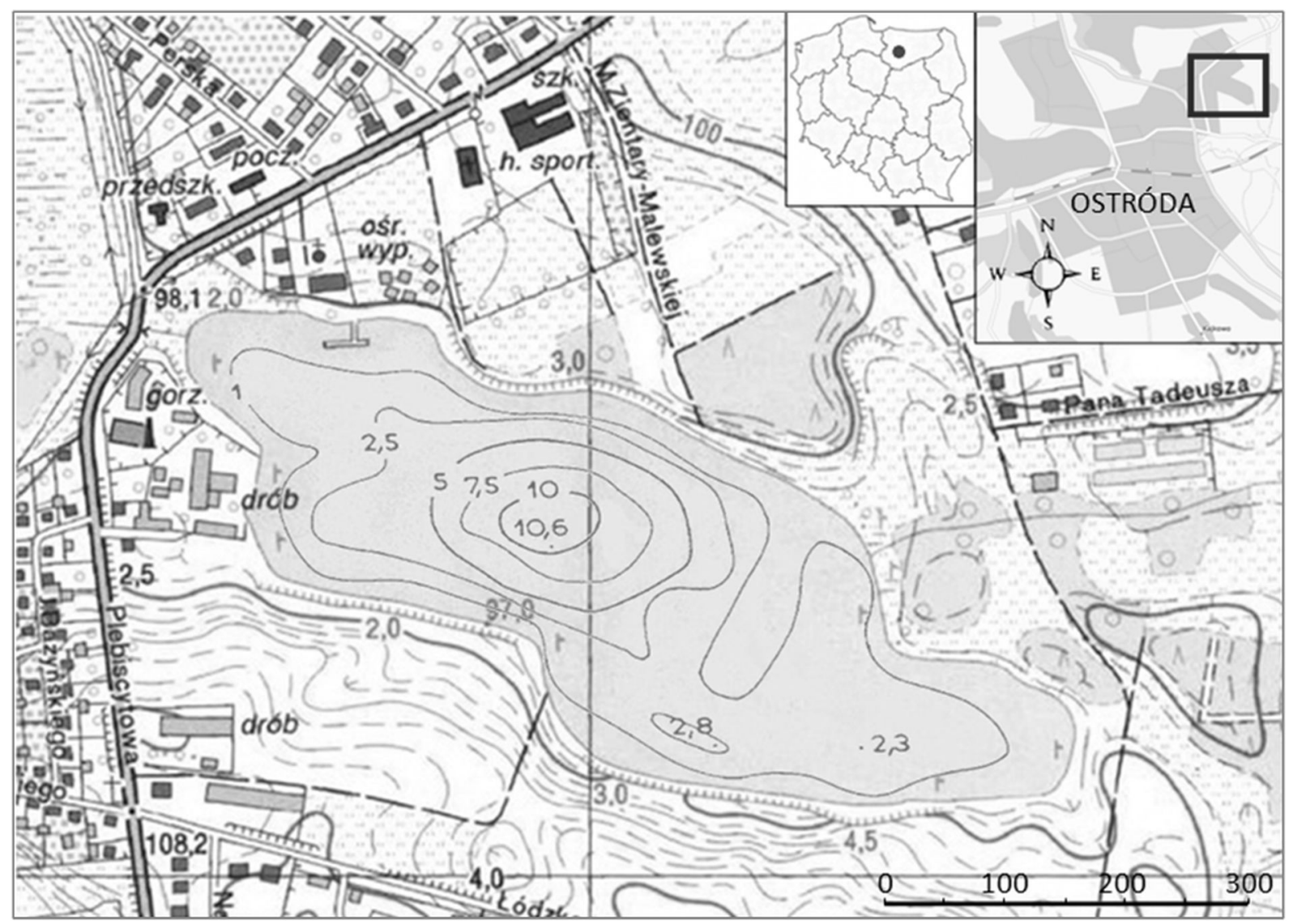

Fig. 1. The location of Lake Paskierz 
Table 1. Morphometric parameters of Lake Paskierz

\begin{tabular}{lc}
\hline \multicolumn{1}{c}{ Parameter } & Value \\
\hline Surface area [ha] & 14.3 \\
\hline Volume $\left[\right.$ dam $\left.^{-3}\right]$ & 364.3 \\
\hline Maximum depth [m] & 10.6 \\
\hline Mean depth [m] & 2.6 \\
\hline Relative depth & 0.24 \\
\hline Depth index & 0.24 \\
\hline Maximum length [m] & 750 \\
\hline Maximum width [m] & 250 \\
\hline Shoreline length [m] & 1800 \\
\hline Shoreline development & 1.34 \\
\hline Elongation & 3.0 \\
\hline
\end{tabular}

built-up area (approx. 45\%). Wasteland occupies nearly $34 \%$, arable land and forests respectively around 13 and $9 \%$ (Table 2). On the northern shore of the lake, there is a resort and a swimming bath. Further away from the lake is a school and detached houses. To the west, the lake lies close to a distillery and a poultry farm. The south-western part of the drainage basin is
Table 2. Land use structure in the drainage basin of Lake Paskierz

\begin{tabular}{lcc}
\hline \multicolumn{1}{c}{ Type of land use } & Surface area [ha] & Proportion [\%] \\
\hline Built-up land & 13.2 & 44.9 \\
\hline Waste land & 9.9 & 33.7 \\
\hline Arable land & 3.7 & 12.6 \\
\hline Forests & 2.6 & 8.8 \\
\hline Total & 29.4 & 100.0 \\
\hline
\end{tabular}

covered by farmland. South of Lake Paskierz there are factories, trade and service facilities, a few detached houses and a large yacht harbour.

According to the physico-geographical division of Poland (Kondracki 2001), Lake Sajmino (Kajkowskie Lake) is located in the Masurian Lake District (region) and Olsztyńskie Lake District (meso-region). The lake is situated southeast of Ostróda. The water table is approximately 101.3 metres above sea level (Fig. 2).

This is an elongated lake, with a poorly developed shoreline and muddy-sandy bottom. The maximum depth is $7.8 \mathrm{~m}$ and the average depth is $3.8 \mathrm{~m}$ (Jańczak et al. 1997) (Table 3). In the southern part

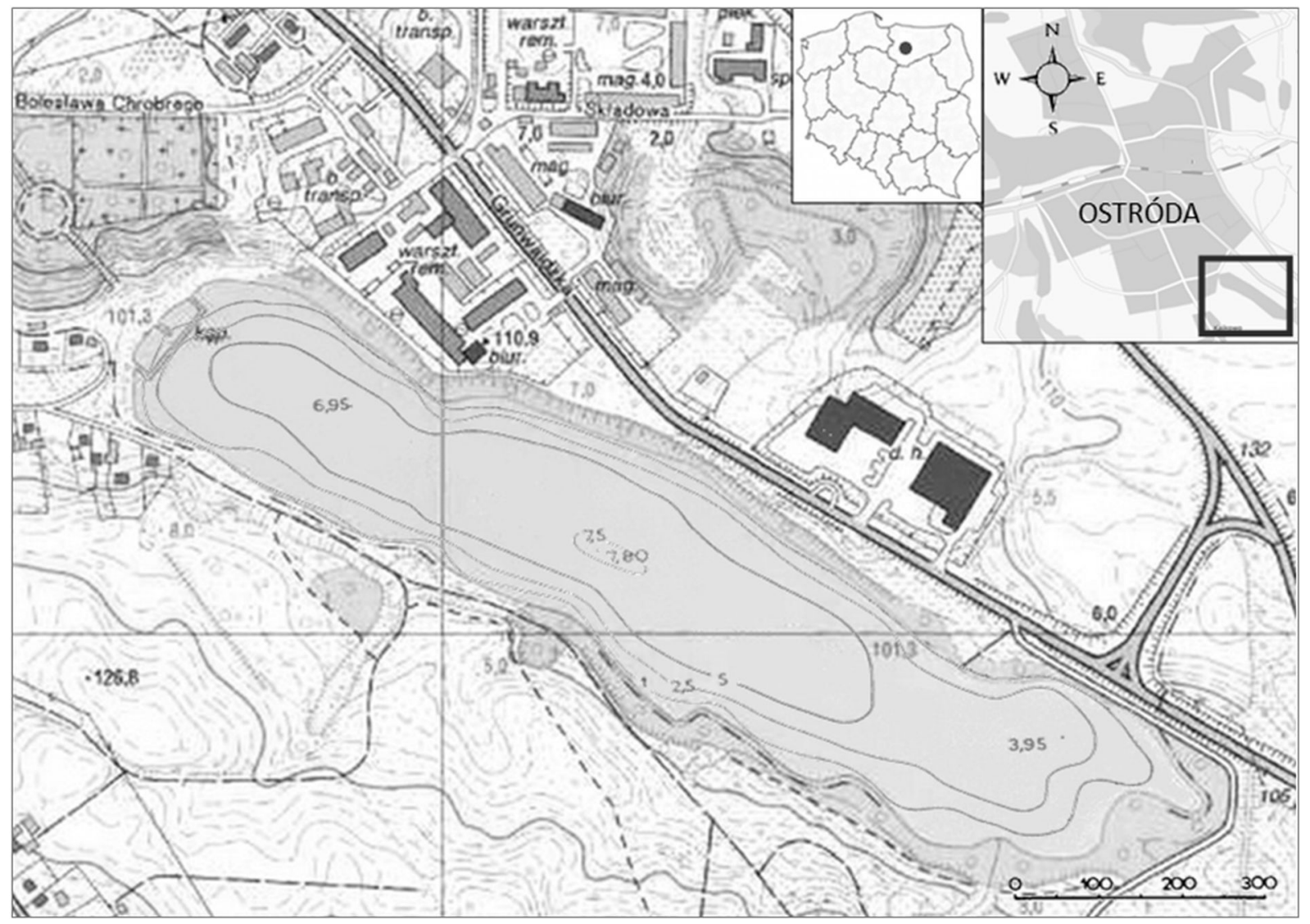

Fig. 2. The location of Lake Sajmino 
Table 3. Morphometric parameters of Lake Sajmino

\begin{tabular}{lc}
\hline \multicolumn{1}{c}{ Parameter } & Value \\
\hline Surface area [ha] & 26.1 \\
\hline Volume $\left[\right.$ dam $^{-3}$ ] & 817.0 \\
\hline Maximum depth [m] & 7.8 \\
\hline Mean depth [m] & 3.1 \\
\hline Relative depth & 0.015 \\
\hline Depth index & 0.4 \\
\hline Maximum length [m] & 1350 \\
\hline Maximum width [m] & 270 \\
\hline Shoreline length [m] & 3000 \\
\hline Shoreline development & 1.66 \\
\hline Elongation & 5.0 \\
\hline
\end{tabular}

of the lake, there is a small island. The eastern shores are marshy, overgrown with reeds, while the northern shores are sandy. The slopes are gentle and easily accessible (Anon. 2009).

The surface of the direct catchment area of Lake Sajmino is 66.5 ha, of which $46.5 \%$ is wasteland, approximately $35 \%$ is arable land, $12 \%$ is covered by forests and $6 \%$ is occupied by built-up land (Table 4 ). To the north of the lake, there are industrial plants, trade and service facilities, and some farmland. The south and south-east side of the lake borders mostly wastelands. A little further away there are arable lands and buildings of Kajkowo Village. A small watercourse flows into the south-eastern end of the lake. The lake is also supplied with water from Sement Maly Lake and receives rainwater from Kajkowo Village. On the western shores of the lake, there are swimming beaches used by residents of Ostróda. Most of the lake shore zone is surrounded by trees.

Table 4. Land use structure in the drainage basin of Lake Sajmino

\begin{tabular}{lcc}
\hline \multicolumn{1}{c}{ Type of land use } & Surface area [ha] & Proportion [\%] \\
\hline Build-up land & 4.0 & 6.0 \\
\hline Waste land & 30.9 & 46.5 \\
\hline Arable land & 23.4 & 35.2 \\
\hline Forests & 8.2 & 12.3 \\
\hline Total & 66.5 & 100.0 \\
\hline
\end{tabular}

\section{Methods}

The material was collected three times: in spring (May), summer (August) and autumn (November) 2011. The sampling stations were located above the deepest points of these lakes, where different inputs are integrated and, according to the authors, best represent average conditions. Water for analyses was sampled using a 3.5-litre Ruttner sampler. To determine the vertical variation of nitrogen forms, samples were collected from the depths of $1 \mathrm{~m}$ below the water surface and $1 \mathrm{~m}$ above the bottom. Water for analysis was transported and stored in glass bottles in a dark refrigerator at $4^{\circ} \mathrm{C}$.

Ammonium nitrogen was determined spectrophotometrically (MERCK SQ 118), nitrite nitrogen was determined with sulphanilic acid and a-naphthylamine hydrochloride (NANOCOLOR UV/VIS, by the company MACHEREY-NAGEL), nitrite nitrogen was determined with phenoldisulphonic acid (NANOCOLOR UV/VIS, by the company MACHEREYNAGEL), organic nitrogen was calculated as the difference between Kjeldahl nitrogen and ammonium nitrogen, total nitrogen was calculated as the sum of Kjeldahl nitrogen, nitrate nitrogen and nitrite nitrogen, and Kjeldahl nitrogen was determined by distillation. Chemical laboratory analyses were conducted according to the standard methodology recommended by Hermanowicz et al. (1999) and Polish Standards. The results were converted to average concentrations. The percentage shares of the various forms of nitrogen in the overall amount of this element were also estimated. Calculations were made using Microsoft Office 2010 Excel Package.

\section{Results}

The concentration of total nitrogen ranged from 1.03 to $6.58 \mathrm{~g}$ Ntot $\mathrm{m}-3$. In the surface waters, the highest concentration (1.98 g Ntot $\mathrm{m}-3)$ was determined in Lake Paskierz in summer and the lowest concentration (1.03 g Ntot $\mathrm{m}-3$ ) was found in the other lake in spring. A similar situation was at the bottom, where the maximum value of this parameter $(6.58$ g Ntot m-3) was also observed during the summer stagnation (Lake Paskierz) and minimum (1.04 g Ntot $\mathrm{m}-3$ ) during the spring circulation (Lake Sajmino).

The organic fraction of total nitrogen was a dominant form in the surface water layers of the examined lakes. The highest percentage in both lakes 
was observed in spring and summer (more than 93\%). A slightly different situation was found in near-bottom water layers of Lake Paskierz, where ammonium nitrogen was the dominant form $(72.9 \%)$ in the summer stagnation. In other cases organic nitrogen was a dominant form in each of the reservoirs (Fig. 3).

Concentrations of ammonium nitrogen in the analysed lakes ranged in wide range, from analytical zero to $4.80 \mathrm{~g} \mathrm{~N}-\mathrm{NH} 4 \mathrm{~m}-3$. For the surface water layers, the maximum concentration of this parameter (0.19 $\mathrm{g} \mathrm{N}-\mathrm{NH} 4 \mathrm{~m}-3)$ was recorded in autumn (Lake Sajmino). In turn, during the spring neither of the examined lakes contained ammonium nitrogen. At the bottom, Lake Paskierz (August) was characterized by the significantly highest ammonium nitrogen concentration (4.80 g N-NH4 m-3). During the summer stagnation at the near-bottom layers of Lake Sajmino this form of nitrogen was not observed (Table 5).

In the surface waters of both lakes, the highest average concentrations of ammonium nitrogen were low (approximately $0.07 \mathrm{~g} \mathrm{~N}-\mathrm{NH} 4 \mathrm{~m}-3$ ). In turn, at the bottom of Lake Paskierz the average concentration of this parameter was $2.35 \mathrm{~g} \mathrm{~N}-\mathrm{NH} 4 \mathrm{~m}-3$, which was more than 22-fold higher compared to Lake Sajmino (Table 5).

The concentration of nitrite nitrogen ranged from 0.00 to $0.14 \mathrm{~g} \mathrm{~N}-\mathrm{NO} 2 \mathrm{~m}-3$. In the surface water

Table 5. Concentrations of nitrogen in water of lakes Paskierz and Sajmino (surf. - surface, bot. - bottom, nd - not detected)

\begin{tabular}{|c|c|c|c|c|c|c|c|c|c|c|c|c|c|}
\hline \multirow{3}{*}{ Nitrogen form } & \multirow{3}{*}{ Unit } & \multicolumn{6}{|c|}{ Lake Paskierz } & \multicolumn{6}{|c|}{ Lake Sajmino } \\
\hline & & \multicolumn{2}{|c|}{ May } & \multicolumn{2}{|c|}{ August } & \multicolumn{2}{|c|}{ November } & \multicolumn{2}{|c|}{ May } & \multicolumn{2}{|c|}{ August } & \multicolumn{2}{|c|}{ November } \\
\hline & & surf. & bot. & surf. & bot. & surf. & bot. & surf. & bot. & surf. & bot. & surf. & bot. \\
\hline Total nitrogen & \multirow{5}{*}{$\mathrm{g} \mathrm{N} \mathrm{m}^{-3}$} & 1.68 & 5.34 & 1.98 & 6.58 & 1.86 & 1.86 & 1.03 & 1.04 & 1.44 & 1.54 & 1.61 & 1.84 \\
\hline Ammonium nitrogen & & nd & 2.05 & 0.02 & 4.80 & 0.19 & 0.20 & nd & 0.15 & nd & nd & 0.19 & 0.17 \\
\hline Nitrite nitrogen & & 0.06 & 0.14 & nd & nd & 0.12 & 0.14 & nd & nd & nd & nd & 0.02 & 0.02 \\
\hline Nitrate nitrogen & & 0.05 & 0.05 & 0.07 & 0.09 & 0.17 & 0.15 & 0.06 & 0.12 & 0.10 & 0.14 & 0.07 & 0.08 \\
\hline Organic nitrogen & & 1.57 & 3.10 & 1.88 & 1.70 & 1.39 & 1.38 & 0.97 & 0.78 & 1.34 & 1.40 & 1.33 & 1.57 \\
\hline
\end{tabular}

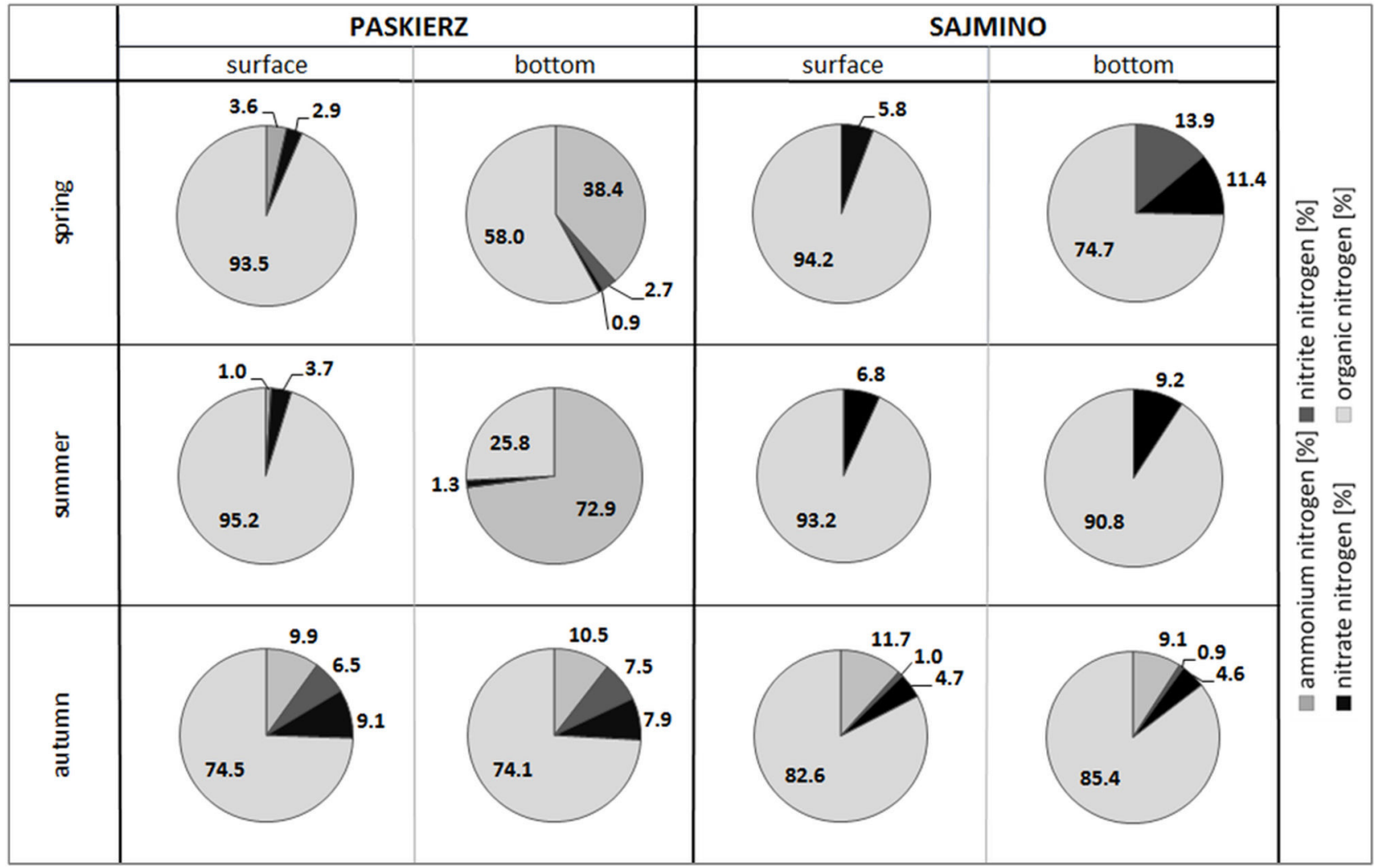

Fig. 3. The share of different forms of nitrogen in the total content of this element in the examined lakes 
layers, the maximum value of the analysed form (0.12 $\mathrm{g} \mathrm{N}-\mathrm{NO} 2 \mathrm{~m}-3$ ) was determined in autumn (Paskierz). In other cases, there was no concentration of nitrite nitrogen or it was very low. In turn, in the near-bottom water layers, the maximum value of this parameter (0.14 g N-NO2 m-3) was observed during spring and autumn circulations in Lake Paskierz. However, in the summer, there was no nitrite nitrogen in the examined reservoirs. The same situation was observed in spring, at the bottom of Lake Sajmino. Concentrations of this fraction did not affect essentially the overall amount of nitrogen in the studied lakes.

The observed concentrations of nitrate nitrogen in the analysed lakes were low. In the surface water layers, the maximum concentration of this form $(0.17$ $\mathrm{g} \mathrm{N}-\mathrm{NO} 3 \mathrm{~m}-3$ ) was found in autumn (Paskierz) while the minimum (0.05 g N-NO3 $\mathrm{m}-3$ ) was in spring, also in Lake Paskierz. The same values were respectively the highest and the lowest concentrations of nitrate nitrogen of the whole analysed cycle. For the nearbottom water layers the highest concentration of the analysed form (0.14 g N-NO3 m-3) was observed in Lake Sajmino (August) while the lowest $(0.05 \mathrm{~g}$ $\mathrm{N}-\mathrm{NO} 3 \mathrm{~m}-3$ ) in Lake Paskierz (May). The average concentrations of nitrate nitrogen in both lakes were close and reached about $0.10 \mathrm{~g} \mathrm{~N}-\mathrm{NO} 3 \mathrm{~m}-3$ (Table 5).

Organic nitrogen variability analysis showed that the concentration of this ratio ranged from 0.78 to $3.10 \mathrm{~g}$ Norg $\mathrm{m}-3$. In the surface water layer, the highest concentration of this form of nitrogen ( $1.88 \mathrm{~g}$ Norg m-3) was noted in Lake Paskierz (August) and the lowest one $(0.97 \mathrm{~g}$ Norg $\mathrm{m}-3)$ in Lake Sajmino (May). Also at the bottom, maximum concentration (3.10 g Norg $\mathrm{m}-3$ ) was observed in Lake Paskierz in the summer and the minimum one ( $0.78 \mathrm{~g}$ Norg $\mathrm{m}-3)$ in spring in Lake Sajmino (Table 4). Both in the surface and in the bottom layers, the highest average concentrations of organic nitrogen were found in the waters of Lake Paskierz and they were $1.61 \mathrm{~g}$ Norg $\mathrm{m}-3$ and $2.06 \mathrm{~g}$ Norg $\mathrm{m}-3$, respectively (Table 5).

\section{Discussion}

Nitrogen circulation in a lake is a complex process, which depends on hydrobiological, hydrochemical and meteorological factors. In addition, it is conditioned by morphometric parameters of a water body, geochemical characteristics of its drainage basin and the type and intensity of anthropopressure (Jarosiewicz and Hetmański 2009; Tilahun and Ahlgren
2010). The concentration of various forms of nitrogen in the waters of the analysed lakes was characterized by a marked seasonal variation.

The dominant share of organic nitrogen in the surface layers of water, especially during the summer stagnation, was related to the intensive development of autotrophs, which indicates the eutrophic character of the lakes. In turn, low concentrations of ammonium nitrogen in the surface layers may be associated with the assimilation of this form by organisms (algae, bacteria) which use it as a substrate for the growth of biomass (Szpakowska et al. 2003; Marszelewski 2005; Li et al. 2006).

Recirculation of nitrogen from the surface layer of sediments, which contains up to $90 \%$ of total nitrogen in the whole ecosystem, produced a strong effect on higher concentrations of ammonium nitrogen in the bottom layer. This phenomenon was particularly visible during the summer in Lake Paskierz, where the ammonium nitrogen concentrations in the bottom layers of water were 200 -fold higher than in the surface, reaching $4.80 \mathrm{~g} \mathrm{~N}-\mathrm{NH} 4 \mathrm{~m}-3$. Such a high concentration of ammonium nitrogen in this zone was related to oxygen deficiency, which encourages nitrogen release from sediment reserves. This is typical of eutrophic lakes (Liikanen and Martikainen 2003; Grochowska et al. 2011; Ozkundakci et al. 2011).

Residual concentrations of nitrite nitrogen were associated with the unstable character of this fraction. In turn, low concentrations of nitrate nitrogen indicated a high level of their utilization by autotrophic organisms (Kajak 2001).

The total amount of nitrogen in Lake Sajmino ranged from $1.03 \mathrm{~g}$ Ntot $\mathrm{m}-3$ to $1.84 \mathrm{~g}$ Ntot $\mathrm{m}-3$, In turn, the concentration of total nitrogen in Lake Paskierz was from $1.68 \mathrm{~g}$ Ntot $\mathrm{m}-3$ to $6.58 \mathrm{~g}$ Ntot $\mathrm{m}-3$, indicating significantly higher fertility and productivity of waters in this lake.

Strong anthropopressure observed in Lake Paskierz results from the fact that the lake's drainage basin, although a small one, is largely transformed by people. Built-up areas account for nearly $45 \%$ of its surface, with a large share of industrial plants (distillery, poultry farms, boat factory). This lake is also characterized by high, quite steep banks, only scantily overgrown by plants. This promotes both nutrient surface runoff and erosion processes. Moreover, the lake has disadvantageous morphometric features, which is why it was classified in the third degradation susceptibility category. Therefore, the lake is highly vulnerable 
to external influences. It should also be noted that 25 years ago Lake Paskierz was considered as overfertilized, characterized by high primary production, containing waters beyond the classification system (Anon. 2009).

Lake Sajmino also has high sensitivity to external influences. Thus, there is a risk of rapid deterioration of its water quality. In addition, Lake Sajmino receives sewage from Kajkowo Village and water from Górczyńskie Lake, highly eutrophic and susceptible to degradation (Environmental Programme 2009). The nitrogen inflow from the drainage basin is to some extent reduced by the trees which grow along much of the lake's shoreline and by the reed-covered gentle slopes (Sidoruk and Potasznik 2009).

\section{Conclusions}

Based on the results, it can be concluded that Lake Paskierz is overfertilized. The high concentrations of ammonium nitrogen observed in near-bottom water layers of the lake indicate that the internal supply may be a very important process affecting the trophic status. The other lake (Lake Sajmino) was characterized by significantly less nitrogen abundance, although the periodically increasing nitrogen concentration reveals the presence of adverse anthropopressure on the lake.

\section{References}

Anon., 2009, Program ochrony środowiska dla miasta Ostródy na lata 2009-2012, z uwzględnieniem lat 20132016 (Environmental Programme for the City of Ostróda for the years 2009-2012, including the years 20132016) 2009 [manuscript], Ostróda, p. 92 (in Polish).

Bajkiewicz-Grabowska E., 2002, Obieg materii w systemach rzeczno-jeziornych (Circulation of matter in the riverlake systems), PWN, Warszawa, p. 274 (in Polish, English summary).

Choiński A., 2007, Limnologia fizyczna Polski (Physical limnology of Poland), Wyd. UAM, Poznań, p. 547 (in Polish).

Camargo J.A., Alonso A., 2006, Ecological and toxicological effects of inorganic nitrogen pollution in aquatic ecosystems: A global assessment, Environ. Int. 32(6): 831-849.

Grochowska J., Łopata M., Parszuto K., Tandyrak R., Wiśniewski G., 2011, Wstępna charakterystyka hydrochemiczna kompleksu jezior barczewskich (Preliminary hydrochemical characteristics of barczewskie lakes), [in:] Marszelewski W. (ed.), Anthropogenic and natural transformations of lakes. Vol. 5, PTLim, Toruń: 47-55 (in Polish, English summary).
Hermanowicz W., Dojlido J., Dożańska W., Koziorowski B., Zerbe J., 1999, Fizyczno-chemiczne badanie wody i ścieków (Physico-chemical examination of water and wastewater), Arkady, Warszawa, p. 556 (in Polish).

Hu Z., Lee J.W., Kartik Ch., Kim S., Sharma K., Khanal S.K., 2013, Nitrogen transformations in intensive aquaculture system and its implication to climate change through nitrous oxide emission, Bioresour. Technol. 130: 314-320.

Jańczak J., 1997, Atlas jezior Polski. Tom 2 (The atlas of Polish lakes. Vol. 2), Bogucki Wyd. Nauk., Poznań, p. 256 (in Polish).

Jarosiewicz A., Hetmański T., 2009, Sezonowa zmienność stężenia substancji biogenicznych w wodach jeziora Dobra (Pojezierze Pomorskie): poziom trofii jeziora (Seasonal changes in nutrient concentration in Lake Dobra (Pomeranian Lake District): trophic state of the lake), Słupskie Pr. Biol. 6: 71-79 (in Polish).

Kajak Z., 1979, Eutrofizacja jezior, PWN (Eutrophication of lakes), Warszawa, p. 232 (in Polish).

Kajak Z., 2001, Hydrobiologia - Limnologia. Ekosystemy wód śródlądowych (Hydrobiology - limnology. Ecosystems of inland waters), PWN, Warszawa, p. 360 (in Polish).

Kondracki J., 2001, Geografia regionalna Polski (Regional Geography of Poland), PWN, Warszawa, p. 441 (in Polish).

Kostecki M., Krodkiewska M., 2005, Zbiornik Paprocany: limnologia-hydrobiologia (Paprocany Reservoir: limnology-hydrobiology), Pr. Stud. IPIŚ PAN 65: 1-102 (in Polish, English summary).

Li Y., Li Z., Geng Y., Hu H., Yin Ch., Ouyang Y., Gui J., 2006, Effect of N, P concentration on growth rate, Acta Ecol. Sinica 26(2): 317-325.

Liikanen A., Martikainen P.J., 2003, Effect of ammonium and oxygen on methane and nitrous oxide fluxes across sediment-water interface in a eutrophic lake, Chemosphere 52(8): 1287-1293.

Lossow K., 2000, Jeziora - rekultywacja, przegląd metod (Lakes - reclamation, review of methods), Prz. Komunalny 9(108): 91-106 (in Polish).

Marszelewski W., 2005, Zmiany warunków abiotycznych w jeziorach Polski północno-wschodniej (Changes of the abiotic conditions in the lakes of north-east Poland), Wyd. UMK, Toruń, p. 228 (in Polish, English summary).

Ozkundakci D., Hamilton D.P, Gibbs M.M., 2011, Hypolimnetic phosphorus and nitrogen dynamics in a small, eutrophic lake with a seasonally anoxic hypolimnion, Hydrobiologia 661: 5-20.

Sidoruk M., Potasznik A., 2011, Stan trofii jeziora Symsar i możliwości jego poprawy (The trophic status of Symsar Lake and possibilities of improvement), Inż. Ekol. 26: 221-229 (in Polish).

Szpakowska B., Karlik B., Gaca W., 2003, Migracja wodna form azotu i fosforu w małej zlewni rolniczej (Water migration of nitrogen and phosphorus forms in a small drainage catchment), Zesz. Nauk. AR Krak., Inż. Środ. 404(24): 347-354 9in Polish, English summary). 
Tilahun G., Ahlgren G., 2010, Seasonal variations in phytoplankton biomass and primary production in the Ethiopian Rift Valley lakes Ziway, Awassa and Chamo - The basis for fish production, Limnologica 40(4): 330-342.
Upadhyay R., Pandey A.K., Upadhyay S.K., Bassin J.K., Misra S.M., 2011, Limnochemistry and nutrient dynamics in Upper Lake, Bhopal, India, Environ. Monit. Assess. 184(11): 7065-7077. 